\title{
Editorial
}

Cerebrovascular

Diseases

\section{Awaken, You Arteries and Limbs!}

\author{
Christian Foerch $^{\mathrm{a}}$ Michael G. Hennerici ${ }^{\mathrm{b}}$ \\ a Department of Neurology, Goethe-University, Frankfurt am Main, and ${ }^{b}$ Department of Neurology, \\ Universitätsmedizin Mannheim, University of Heidelberg, Heidelberg, Germany
}

Without doubt, Johann Sebastian Bach (1685-1750) is one of the greatest composers in history and the mastermind of music in the baroque epoch. During his life, he created an incredibly manifold and sophisticated magnum opus. One of his duties - or at least what he considered to be his duty - as the Chief Cantor at the Thomaskirche, Leipzig's leading Lutheran church at the time, was to write brand new cantatas on a weekly basis and to perform them during the regular Sunday services throughout the ecclesiastical year. At least 3 complete year-round cycles of Bach's cantatas originated from the mid-1720s. It is difficult to imagine how Bach was able to achieve this given the numerous other demands on him as organist, conductor of the Thomaner-choir, music teacher and the father of numerous children.

Bach prepared his cantata Unser Mund sei voll Lachens ('May our mouth be filled with laughter', BWV 110) for Christmas Day, 1725. It was the third Christmas feast he had celebrated while being the Thomaskantor in Leipzig, and he was still motivated enough to want to impress his audience with another illuminating piece of work. As was the case with his Christmas cantatas from the 2 preceding years, Bach wrote an exciting and powerful piece of music for this essential holiday, which required 4 soloists, a 4-part choir and a large orchestra comprised of trumpets, kettledrums, oboes, flutes, the bassoon, strings and a basso continuo.

\section{KARGER 125\%}

2015 S. Karger AG, Base

$1015-9770 / 15 / 0406-0301 \$ 39.50 / 0$

E-Mail karger@karger.com

www.karger.com/ced
The lyrics of Bach's cantatas are in part based on bible citations, with contemporary poetry and words from traditional German church chorales added for completeness. The cantata Unser Mund sei voll Lachens includes words from Psalm 126, Jeremiah 10 and the second chapter of Luke (parts 1, 3 and 5 of the cantata). The lyrics of parts 2, 4 and 6, however, were written by Georg Christian Lehms (1684-1717), a virtuous German poet who was dying from tuberculosis at a rather young age. The lyrics of the final chorale are based on a traditional church song attributed to Kaspar Füger, a 16th century priest. Designed for Christmas Day, the cantata in its opening section truly makes us want to 'fill our mouth with laughter' and to praise God for his coming to Earth, a good deed for all mankind. It then describes the salvation that originates from the Christmas miracle: the sinner turns into a child of God. The final parts again glorify the Lord.

The baroque period was the main era for musical rhetoric and included key elements such as the Figurenlehre ('doctrine of figures') and the Affektenlehre ('doctrine of affects'). Music was considered to be a 'tone language'. The content and meaning of written words were illustrated and interpreted by their careful translation into music using a large repertoire of 'figures' and other stylistic techniques. In simple terms, high notes were used to illustrate mountains and the sky, low notes represented valleys and hell, and chromatic and dissonant intervals

Christian Foerch, MD

Department of Neurology, Goethe-University Schleusenweg 2-16

DE-60528 Frankfurt am Main (Germany)

E-Mail foerch@em.uni-frankfurt.de 
Fig. 1. Bach's autograph of the aria Wacht auf, ihr Adern und ihr Glieder ('Awaken, you arteries and limbs'). Shown are measures 12-19, including the start of the bass soloist in measure 13. The words can hardly been read in Bach's hand writing, but the soloist's ascending D major triads (measure 13) and the swirling notes in the first violin (measures 14-16) illustrating the 'awaking arteries and limbs' are easy to recognize. Trp = Trumpet; $\mathrm{Vl}=$ violin; $\mathrm{Va}=$ viola; $\mathrm{Bc}=$ basso continuo. From Mus. ms. Bach P 153, Staatsbibliothek zu Berlin, Preussischer Kulturbesitz, www.bach-digital. de, with kind permission.

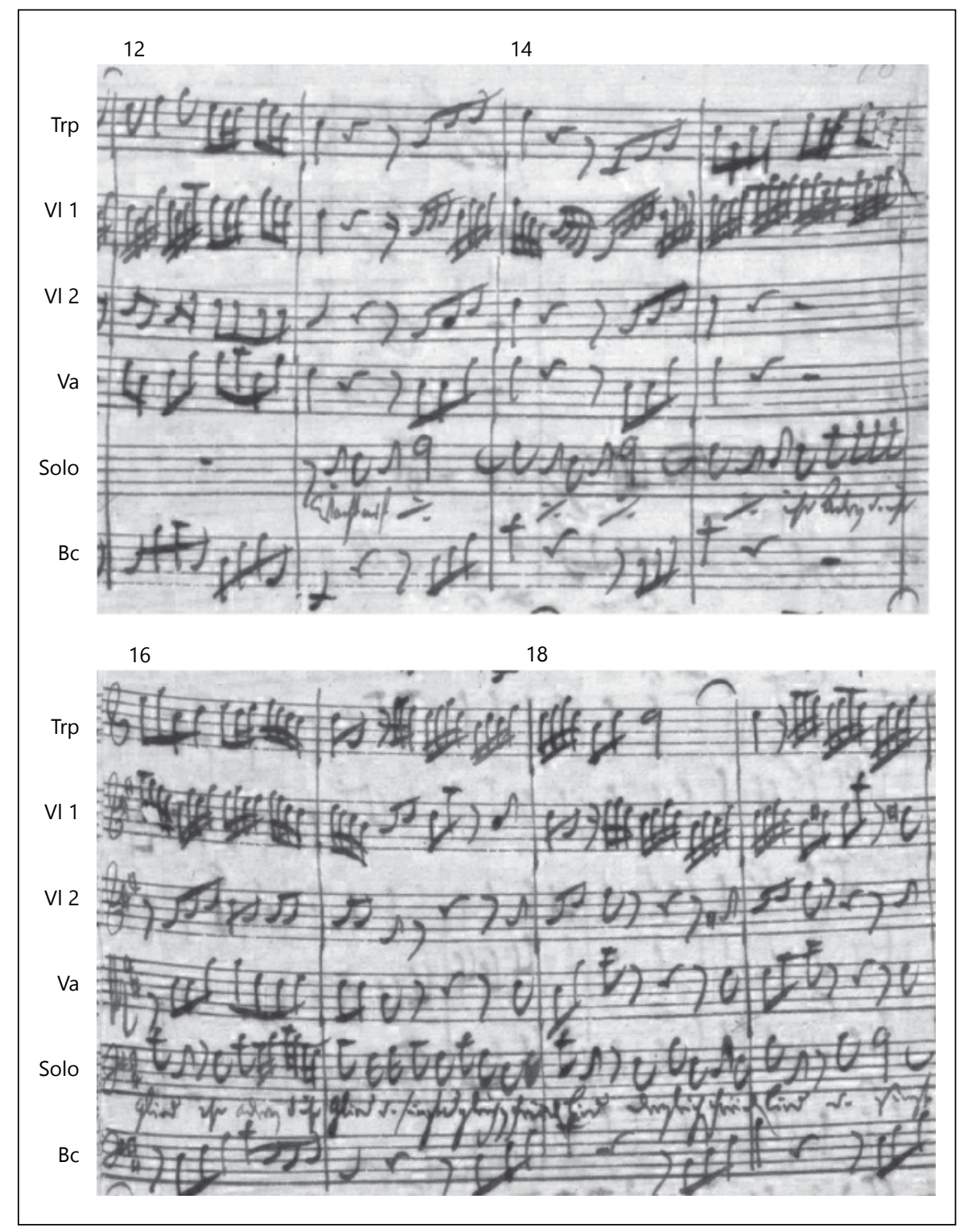

mimicked mourning and pain. There are hundreds of examples in Bach's music of the use of musical rhetoric in its perfection. Particularly famous is the curtain of the temple of Jerusalem, which was torn into 2 pieces during the tremendous storm that allegedly followed Christ's crucifixion. In one of his masterpieces, the St. Matthew Passion, Bach translated this scene into music and used a rapidly ascending tone sequence spreading over several octaves to illustrate the tearing of the curtain. In the cantata Unser Mund sei voll Lachens, Bach perfectly imitated the laughter of people in the magnificent opening chorus, which he incidentally adapted from his French Overture of the fourth orchestral suite (BWV 1069), a sign that sometimes even the most organized and creative composer may have struggled with deadline constraints. Following the majestic, pure instrumental opening, the choir accompanies a fugal section that is characterized by ascending triplets and sharply dotted eighth notes. The unsteady and rapidly changing rhythms of these musical elements in combination with single notes followed by breaks impressively mimic the irregular shape of laughter.

From a medical perspective, of course, the start of the basso aria (part 6 of the cantata; fig. 1) is of particular interest. The text starts with an unambiguous call that is somewhat uncommon and surprising: Wacht auf, ihr 
Adern und ihr Glieder ('Awaken, you arteries and limbs'). Nearly 300 years later, many stroke neurologists may have a similar thought in mind when commencing risky thrombolysis infusions in their aphasic or hemiparetic patients. It is striking to see how Bach rhetorically sets the issue of awakening arteries and awakening limbs into music - a baroque hymn on brain vessel recanalization. At this stage of the cantata, following the glorious opening and some more meditative tones that arise from the arias in the middle section, Bach wants to activate everyone and anything, including arteries, limbs and the 'devoted strings' to let them sing songs of joy upon the occasion of Christ's birth. Regarding the conception of the aria, the prominent part of the bass soloist, which is generally considered to be mimicking the voice of the pastor, is supported by the strong sounds of a trumpet. The aria starts with a profound D major accord, followed by a trumpet signal in a characteristic D major triad, which may well have been regarded as a wake-up call in the early morning hours in the olden days. Then, the violins set in and start to build; they undulate and undertake various attempts to climb and reach the highest notes, like the various attempts the pulsating blood needs to make to burst the occlusive thrombus. These signs of awakening and climbing are also accompanied by ascending triads in the basso continuo part. In the 13th measure, the bass soloist comes in with the same triad that was initially provided by the trumpets. While prompting the words Wacht auf, ihr Adern und ihr Glieder ('Awaken, you arteries and limbs'), the violins start to rise again - certainly an innervating scene! Then, a rather quieter middle section ends with an allusion to what happens after a successful stroke treatment - both heart and spirit are delighted.

An article about medical issues in Bach's compositions should not end without a few words on the health of the great composer himself. For many years, Bach apparently had no physical problems, apart from being nearsighted. However, it has been suggested that based on his 'tem- perament, nature and stature', he may have had vascular risk factors such as arterial hypertension and diabetes mellitus. Derived from a contemporary portrait of the composer, some sources have even suggested that Bach had suffered a minor stroke, causing persistent facial asymmetry. What is certain is that in his later years, he developed a 'serious and painful eye disease' that was probably glaucoma. This was clearly disabling, as he was no longer able to compose as usual. Some of his friends recommended that he undergo eye treatment at the hands of a famous oculist who, at the time (1749/1750), practiced in Leipzig. As a consequence, 'Chevalier' John Taylor performed 2 eye operations on Bach using quite drastic methods that included local irritation of the eye by repeated incisions and cataplasms with excessive use of the entire dubious armamentarium of the times (including calomel, cantharides, bleeding, etc.)'. After the procedure, Bach was unable to see and his vision never recovered. In a dark room, he dictated his last notes, an organ phantasy on the chorale 'I now appear upon Thy throne'. Shortly thereafter, he developed an infection and ultimately suffered a severe stroke that led to his death on July 28,1750 . His creative arteries and limbs thus came to a final rest.

The last chapter of Johann Sebastian Bach's life in terms of medicine is the issue of his mortal remains. After his death, Bach was buried in the graveyard near the St. Johannes church in Leipzig. The exact location of his grave was lost over time, suggesting that very little attention was paid to someone who is now considered to be one of the greatest composers who ever lived. In 1894, parts of the graveyard were remodeled, and a search for Bach's remains began. A skeleton was found which - according to Wilhelm His (1831-1904), a well-known anatomist at the University of Leipzig - matched what was thought to be the anatomic 'structure' of Bach. More recently, however, doubts have been raised as to whether the remains are authentic. 